\title{
Economic study of Gaushalas in Haryana: functioning and profitability
}

\author{
Shweta Bijla and Ajmer Singh
}

Received: 26 September 2018 / Accepted: 17 December 2018 / Published online: 21 February 2019

(c) Indian Dairy Association (India) 2019

\begin{abstract}
Cow is revered by more than $70 \%$ of the population of our country. Although the total cattle population of the country is dominated by indigenous cattle but the population of crossbred cattle has increased significantly. This poses threat to genetic diversity of our indigenous cattle. There is yet another problem of large number of stray cattle in the country and their number is still increasing. They need to be managed properly. Gaushalas are considered to be a good alternative to manage the ever increasing stray cattle population and also to conserve our deteriorating genetic base. Hence it becomes important to study how economically the Gaushalas are managed provided the type of animals they keep; identify their functioning, net returns etc. For this purpose Haryana was selected as this state has initiated many programs for indigenous cattle conservation and particularly for Gaushalas. Both primary and secondary data was taken on different aspects of Gaushala for triennium ending $(2014,15$ \& 16). The major sources of income were donations (75\%) followed by government grants $(8 \%)$, sale of milk $(6 \%)$. Feed and fodder constituted half of the total expenses and $70 \%$ of the operating expenditure of Gaushalas. For the whole sample net income was positive (₹ 14 lakhs per annum). It was highest for Panipat Gaushala (₹ 37.85 lakh per annum), while Bhiwani Gaushala had
\end{abstract}

Shweta Bijla $(\square)$

Division of Dairy Economics, Statistics and Management, ICAR- National Dairy Research Institute, Karnal- 132 001, Haryana, India

E-mail: shwetabijla00@gmail.com, Mobile: +919896027378

Ajmer Singh

Division of Dairy Economics, Statistics and Management, ICAR- National Dairy Research Institute, Karnal- 132 001, Haryana, India the lowest and negative net income (₹ -15.51 lakh per annum). Net income was negative for some Gaushalas because of addition of fixed expense component in total expenses of Gaushalas. On the other hand the average returns over variable cost were positive (₹29.36 lakh per annum) for all the Gaushalas. Operating and gross ratios were found to be 0.73 and 0.97 respectively which shows that though Gaushalas were able to cover their operating expenses but they exhausted almost all of their income to cover their total expenses.

Keywords: Donations, Feed and fodder, Functioning, Genetic diversity, Gaushalas, Indigenous cattle, Income and expenses, Operating ratio, Stray cattle

\section{Introduction}

Earlier India was not much competent in agriculture sector in the world but the two turning points in Indian history i.e. "Green Revolution" and "White Revolution" have changed the scenario of Indian agriculture significantly over the years. Livestock sector currently contributes $25.8 \%$ to agricultural GDP and $4.5 \%$ to country's GDP (Department of Animal Husbandry, Dairying and Fisheries, 2018). India is having more than half of the cattle of the world. Although the total cattle population is dominated by indigenous cattle with $79 \%$ as against $21 \%$ crossbred cattle population, but the population of crossbred cattle has increased significantly from $7 \%$ in 1992 to $21 \%$ in 2012 , while those of indigenous cattle has declined from $93 \%$ in 1992 to $79 \%$ in last census conducted in 2012 (19 th $^{\text {th }}$ Livestock Census, 2012). This situation sounds the alarm as the diverse genetic base of India is becoming narrow which is a threat to sustainability. Indigenous cattle are source of A2 milk, resistant to harsh weather of the country etc. The main reason for such a declining trend in the population of indigenous cattle can be considered as abandoning of these cattle once they pass their milking stage and become uneconomical to the farmers to feed. These abandoned cattle are either seen scrounging in garbage dumps in the cities or will finish up at slaughter house. But cow slaughter is banned in India due to religious taboos. There are several rules and legislations regarding restriction or complete ban on slaughter 
of these animals which makes both cow slaughter and sale of beef cognizable and non-bailable offences.

Hence, solutions to these problems are complex because of the social taboos and various religious sentiments attached to it. There are several attempts to relax the rules on slaughter ban but the states currently making their bans stricter. Farmers are poor and have fewer options. Thus there is a need to find alternative way to manage these animals. The solution lies in maintaining the dairies adequately, creating huge Gaushalas with adequate space and funds, at appropriate locations, which can house thousands of such cattle and proper public and government cooperation.

Need of the hour suggests that Gaushalas provide better alternative to manage these poor cattle. Though Gaushala has diverse purposes, its main aim is to provide shelter to stray cattle, improve the health of infirm, unproductive, diseased and abandoned cattle. Along with that, Gaushalas help in conserving the Indian germplasm and cow progeny. Some Gaushalas are involved in upgrading the local breeds and use them to supply plenty of pure indigenous milk \& other products prepared particularly from cow dung and cow urine and supply the best female calves to the villagers.

But these Gaushalas are facing various problems on several aspects, particularly on economic front due to lack of government support, delays in funding, less space and feed availability etc. Thus it is important to study the economics of Gaushalas so as to find economical ways with which they can run and provide shelter to large number of animals on sustainable basis. There have been plenty of studies on determining the economics of dairy farms, but not much on Gaushalas so far. Hence this paper edifies their functioning, structural organization, income sources, expenditure and hence profitability; thus suggesting the interventions so as to make these Gaushalas viable on long term basis so that they can take care of large number of animals. Though Gaushalas do not work for profit, but it is extremely important for them to have positive net returns so as to keep themselves running since they do not have regular and stable source of income.

This paper attempts to find out the actual economic conditions of Gaushalas in Haryana by analysing their functioning, income and expenditure patterns and finally assessing the profitability of these historical institutions.

\section{Methodology}

\section{Sampling}

Haryana state was selected purposively for the study. The state is a non-coastal state in northern India. The total geographical area of Haryana is $4.42 \mathrm{~m}$ ha which is $1.4 \%$ of total geographical area of the country. The state has contributed significantly to the Green Revolution in India in the 1970s that made the country self-sufficient in food production. Haryana's agriculture GDP contribution to the country is $14.1 \%$. Dairy farming is also an essential part of the rural economy. Haryana has a livestock population of 10 million head. Milk and milk products form an essential part of the local diet which is considered as staple food of the state. Haryana, with 660 grams of availability of milk per capita per day, ranks at number two in the country as against the national average of 232 grams. There is a vast network of milk societies that support the dairy industry. Haryana has emerged as the most proactive state in the country as far as protection and sheltering of Gauvansh is concerned.

Total cattle population in Haryana is $18,08,116$, out of which indigenous cattle consist of about $45 \%$. There are large numbers of registered Gaushalas in Haryana i.e. 392 which maintain about $7 \%$ of total cattle of Haryana. These Gaushalas at present are maintaining more than 3 lakh cattle in the state. Number of stray cattle in Haryana is 1, 17, 209 and this number is increasing incessantly (1 $9^{\text {th }}$ Livestock Census, 2012). These stray cattle also cause huge menace in the form of accidents and crop losses due to grazing in farmers' fields. There is also stricter ban on cow slaughter as compared to other states, according to Haryana Gauvansh Sanrakshan and Gausamvardhan Act, 2015 which replaced the earlier act Punjab Prohibition of Cow Slaughter Act, 1955 due to its ineffectiveness and low conviction rate. Such rules are now becoming stricter due to more attention of the present government in this direction. The state Gaushala Sangh has also formulated minimum standards of processes and procedures for Gaushalas.

Various other schemes for cow protection and conservation of indigenous cattle in Haryana have been started in the recent past like scheme for conservation and development of indigenous cattle (Gausamvardhan) (2015-16), scheme for establishment of Gau Abhayaranya in the state (2015-16) under which 40 Gau Abhayaranya (cow sanctuaries) will be established in the state for accommodation of the stray cattle. Gau Seva Ayog has also been setup for the protection of cows, their breed development and modernization of Gaushalas' infrastructure. (Department of Animal Husbandry \& Dairying, Haryana. 2015). New schemes have also been started namely Nandi gram, Gau Chikitsalya for treatment and upkeep of injured and infirm cattle. First Nandi gram has been inaugurated in Karnal district of the state. There is also a new scheme to open Gaushalas in those jail premises which have adequate space for the purpose. In first phase, it will be opened in six districts of the state and first of these cow sheds will come up in the Karnal district. All these programmes are just in their initiation phase only. Thus to tackle the problems we still have to rely on these primitive cow shelters which still has huge scope of improvement and then being self sustainable, these shelters can fulfil their various objectives leading to welfare of these animals. 


\section{Selection of Districts and Gaushalas}

Based on the information available at official site of Haryana Gaushala Sangh, Department of Animal Husbandry and Dairying, Government of Haryana and other sources such as Gaushala activities, one feasible Gaushala was selected from each of the ten selected district.

Based on the information available at official site of Haryana Gaushala Sangh and Deptt of AH\&VS, Government of Haryana, 10 Gaushalas were selected on the basis of diversified activities in the form of cow protection, breed conservation, production of cow based products etc. Gaushalas from each district were selected from 2-3 active Gaushalas in the districts and those who were supportive in providing required information. Thus, from the eastern side Ambala, Yamunanagar, Karnal, Panipat and Kurukshetra were selected; from the central region Kaithal and Rohtak were selected and Hisar, Bhiwani and Jind were selected from western region of Haryana. Table 1 shows the name of the selected Gaushalas from their respective districts and number of animals kept in them during 2016.

\section{Data}

The present paper is based on both primary and secondary data. Primary data was collected on covered and farm area of the Gaushalas, quantities and prices of milk and other products made, expenditure incurred on green fodder, dry fodder, concentrates, labour and salaries of employees, veterinary expenses, inventory with each Gaushala. Secondary data was collected on the number of Gaushalas in different districts of Haryana, number of animals, their composition, amount of public and other donations, government grants, members contribution, miscellaneous income and expenditures of Gaushalas. The data was collected consecutively for three financial years i.e. 2014, 2015 and 2016 (Triennium ending) which was averaged out for further calculations.

\section{Analytical framework}

\section{Tabular analysis}

We applied tabular analysis to estimate income and expenditure patterns. It consisted of revenues and funds generated in the Gaushalas from various sources and expenses incurred in Gaushalas and finally net income was computed by deducting total expenses from gross income. The various economic parameters such as profitability ratios, self sufficiency, employment generation etc. were worked out with the help of tabular analysis.

\section{Fixed expenses}

Fixed expenses are those which do not vary with the level of output and remain unchanged over a short period of time. The various components of fixed expenses of Gaushalas were salaries of permanent employees working there, depreciation and interest on fixed capital. Capital Recovery Cost method was used to calculate depreciation of the inventory of Gaushalas while Straight Line method was used for calculating the depreciation of cattle kept in there. Interest on fixed capital was not accounted for separately because CRC approach was followed. The salaries of employees were computed by multiplying number of paid employees with their salaries.

\section{Depreciation cost}

It is the loss in the value of an asset due to normal wear and tear, time and obsolescence. It can be accounted with the help of Capital Recovery Cost (CRC) Method. The CRC method is defined as the annual payment that will repay the cost of fixed input over the useful life of input and provide an economic rate of return on investment. The formula for estimation of CRC is:

$$
R=Z\left[\frac{(1+r)^{n} r}{(1+r)^{n}-1}\right]
$$

where,

$$
\begin{array}{lll}
\mathrm{R} & = & \text { Capital recovery cost } \\
\mathrm{Z} & = & \text { Initial value of the capital asset } \\
\mathrm{r} & = & \text { Interest rate } \\
\mathrm{n} & = & \text { Useful life of the assets (years) }
\end{array}
$$

In case of practical difficulties in getting the information on initial outlay at the field level, the current value of asset was considered. When the asset was purchased from borrowed capital the actual interest rate charged by the bank was taken as (r), while in case of owned funds, the interest on term deposit of 1-5 years was taken. The useful life of assets was assumed to be 20 years for cemented cattle shed, 6 years for manual chaff cutter, and 10 years for power operated chaff cutter. The useful life of milch animals also varied with the type of animal and was taken as 10 and 8 years for local cow, crossbred cow, respectively.

On the other hand, for computing the annual amount of depreciation of the cattle, Straight Line method was used. Since information on details of large number of animals was limited, the animals were categorized under broad categories heifer, young stock and adult animals for finding their depreciation.

$$
D=\frac{\mathrm{IV}-\mathrm{JV}}{\mathrm{N}}
$$

where,

$\mathrm{D}=\quad$ Annual amount of depreciation

$\mathrm{N} \quad=\quad$ Initial value of the cattle

$\mathrm{N}=$ Junk Value of the cattle

$\mathrm{N}=$ Useful life of the cattle

\section{Variable expenses}


Variable expenses are those which are incurred on the variable factors of production and can be altered in the short run. Variable cost includes three items i.e. feed and fodder cost, labour cost and veterinary and miscellaneous expenditure.

\section{Feed and fodder expenses}

This includes the cost of feeding dry fodder, green fodder and concentrates and other feed to animals. In case of purchased feed and fodder, the cost was worked out as product of quantity fed to animal and purchase price of respective feed.

\section{Labour expenses}

It comprises of wage payments in cash and kind payment to hired labor of the Gaushalas.

\section{Veterinary and miscellaneous expenses}

The expenditure on health care of the animals was covered under the veterinary expense. It included, cost of artificial insemination, vaccination, medicines, veterinary doctor fees and other related expenses. The miscellaneous expenditure included expenses on repair of fixed assets, water and electricity charges, office and kitchen expenses and any other consequent charges.

\section{Apportionment of joint costs}

Among the various expenditure items discussed above, certain expenses are incurred on the entire herd as a whole. For instance, the fixed assets like cattle shed, stores, mangers, water tub, buckets etc., are jointly used by the entire herd. Also, the information on cost on labour and miscellaneous items was available only for the entire herd as a whole and not for individual animal Therefore, for the apportionment of these joint costs the total number of animal were converted into standard animal units. Land was obtained by Gaushalas in donation.

\section{Regional Standard Animal Units (SAUs)}

Regarding the differences in regional endowments of animal wealth and species, the SAUs have been worked out by Sirohi et al. (2015) for northern plains have been used (Table 2). Most of the earlier studies have considered only labour utilization as the basis of apportionment. In this case, besides labour utilization, the body weight of the animal was also taken into consideration for the estimation of the SAUs. As the study area falls in the northern region so standard animal units for this region were used as below:

\section{Total expenses}

Total expenditure was obtained by adding all the fixed and variable expenses incurred by Gaushalas for triennium ending.

\section{Gross income}

Gross income was calculated by adding the income from all the sources for each Gaushalas. These sources are donations, grants from central and state governments and other sources, returns from sale of milk and milk products, products made from cow urine and dung, scrap sale and other miscellaneous income.

\section{Net income}

Net income for different Gaushalas was calculated by deducting total expenses from total income. After computing net income, net income per standard animal unit was also calculated.

\section{Ratio analysis}

Ratio analysis was attempted to study the economics of Gaushalas from financial management point of view. These ratios can be compared with the established standard or similar economic entities. From the tabular analysis, Ratio Analysis was done. It consists of following ratios:

$$
\begin{aligned}
& \text { Operating Ratio }=\frac{\text { Total operating expenses }}{\text { Gross Income }} \\
& \text { Fixed Ratio }=\frac{\text { Total fixed expenses }}{\text { Gross Income }} \\
& \text { Gross Ratio }=\frac{\text { Total expenses }}{\text { Gross Income }}
\end{aligned}
$$

In order to check the profitability of the Gaushalas, the above ratios were computed. For profitability of Gaushalas, these ratios should be less than one. The operating ratio more than 0.5 is not preferred and it warrants for in depth analysis to control the operating expenses.

\section{Results and discussion}

\section{General profile and functioning of Gaushalas}

This section of the paper gives a brief idea of the general profile and functioning of Gaushalas. General information about total and farm area of the Gaushalas gives us an insight into whether the Gaushalas have sufficient area as well as farm area. Similarly, the composition of animals gives us an idea about the type of animals kept in the Gaushala. Functioning of the Gaushalas gives an idea about the organizational structure, major activities performed by them, their aim etc. Thus, various such aspects are discussed below:

Land is very important to accommodate animals in Gaushala. The increasing population of cows can be maintained properly only when there is adequate space in the Gaushala. The farm area is also important to fulfill the need for green fodder in the Gaushala. The total area and area under fodder crops for the 
Figure 1 Composition of cattle kept in Gaushalas

\section{Per cent Population}

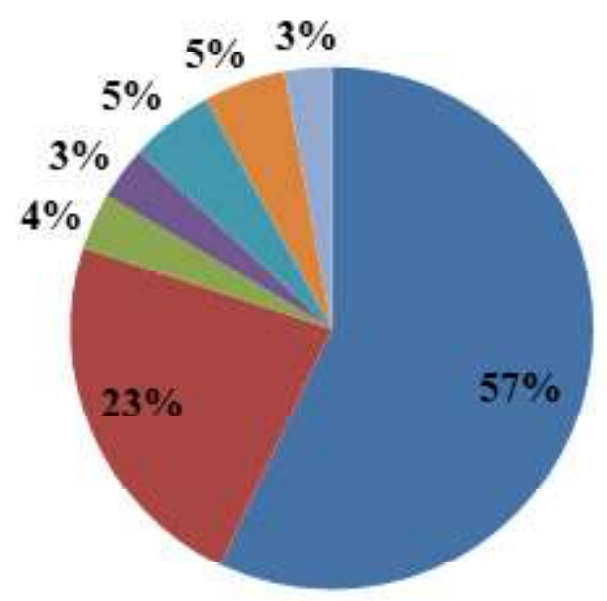

- Adult Female

- Adult Male

- Young stock Male $<1$

n Young stock Female $<1$

- Young stock Male $>1$

= Young stock Female $>1$

- Hiefer

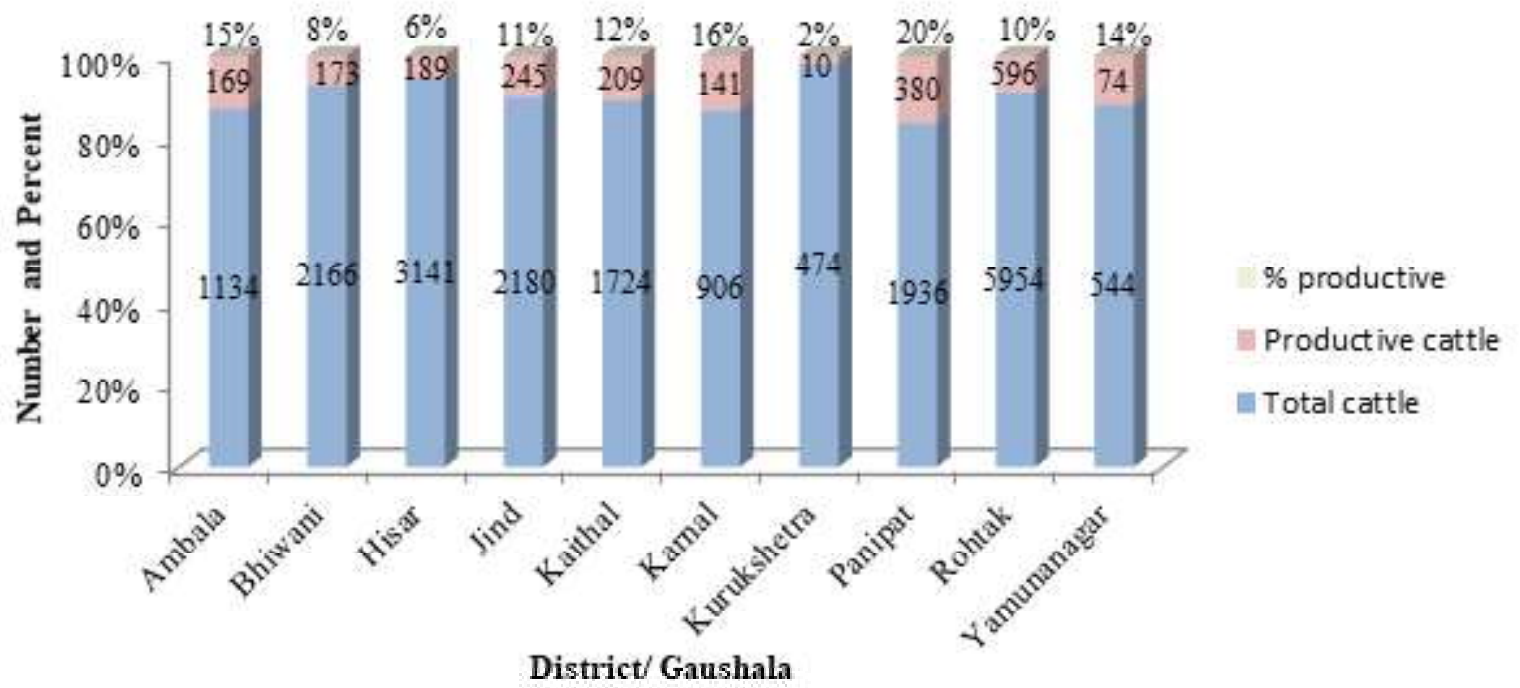

Figure 2 Total and productive cattle across Gaushalas (number and percentage)

sample Gaushalas is depicted in table 3. Panipat Gaushala was found to have highest covered (6.6 ha) as well as farm area (10 ha). Kurukshetra Gaushala had the lowest covered area (1.1 ha). Some Gaushalas like Ambala, Bhiwani, Karnal and Kurukshetra were not having farm area. They completely depend on purchased fodder for feeding cattle. While it was found that some Gaushalas like Yamunanagar and Panipat, they give their land on rent to others for cultivation and other purposes. The Gaushalas in Jind, Kaithal, Hisar, Panipat and Rohtak were cultivating green fodder on their own farm area. On an average, the sample Gaushalas had 3.9 hectare covered area and 5.2 hectare farm area in the study area.

\section{Composition of cattle in Gaushalas}

The composition of herd for the Gaushalas is presented in figure 1. The total cattle population comprised of adult females, adult males, heifers, calves below 1 year age and calves above 1 year age. Figure 1 revealed that the majority of cattle kept in Gaushalas consisted of adult females (57\%) followed by adult males (23\%).

\section{Proportion of productive animals}

Though Gaushalas are mainly established for uneconomical and unproductive cattle, but there are few productive animals which can serve as a source of income to these Gaushalas and contribute towards profitability. The productive animals include in milk and pregnant cows, in milk and not pregnant cows, dry and pregnant cows, pregnant heifers and service bulls. The proportion of productive animals in total animals of Gaushalas is given in figure 2 which shows Panipat Gaushala was having highest proportion of productive animals $(20 \%)$ followed by Karnal $(16 \%)$. The Kurukshetra Gaushala was having least proportion of productive 


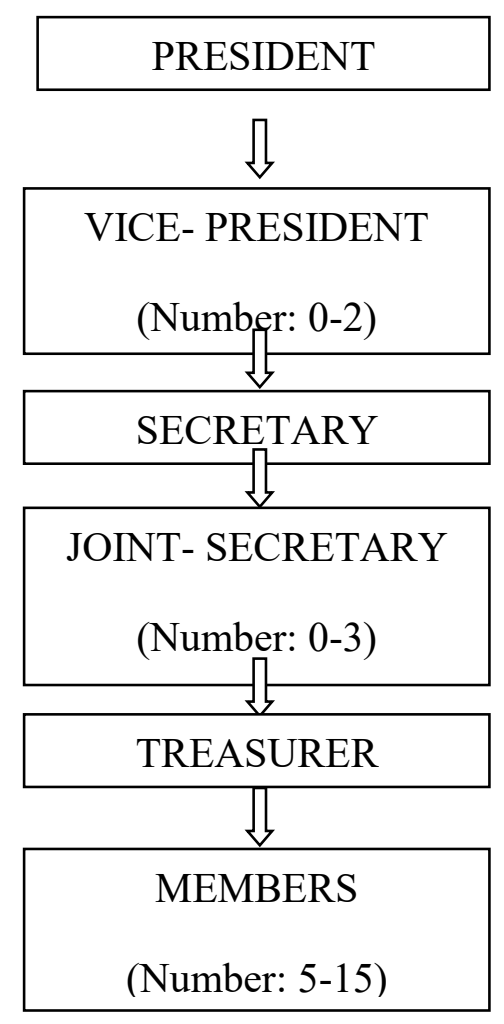

Figure 3 Structure of Gaushala Committee

animals $(2 \%)$. On an average $11 \%$ of the total animals were productive in the sample Gaushalas.

\section{Average production and sale of milk}

Milk was found to be an important source of income of the Gaushalas. Milk yield of a cow depends on a number of factors like breed of the cow and feed and fodder fed to it. In Gaushalas majority of the animals were of local breed and their milk yield is very low. The daily milk yield and its prices are presented in table 4 separately for each Gaushala. Table 4 depicts the average daily milk produced and sold in Gaushalas with its prices. The highest quantity of milk produced was in Karnal Gaushala (525 litre) out of which it was selling 467 litre per day at $₹ 44$ per litre followed by Kaithal and Panipat. Some Gaushalas like Hisar, Jind and Kurukshetra Gaushalas were not selling any milk and they use whole of the milk produced in the Gaushala itself. These Gaushalas were also having low proportion of productive animals. On an average seven Gaushalas in the study area were selling $90 \%$ of the milk produced in the Gaushala at an average price of ₹42 per litre.

\section{Functioning and income and expenditure patterns of gaushalas}

\section{Organizational Structure of Gaushalas}

The Gaushalas are run in the name of a registered trust or society. The trust or society can be started by some founder or saint, Non Governmental Organizations/ Self Help Groups or Village Panchayats. Each Gaushala has an executive committee known as Gaushala committee. The generalized structure of Gaushala management committee henceforth called as Gaushala committee is given in figure 3 .

Apart from executive committee, some Gaushalas also have Manager and Supervisor. The committee is selected through mutual understanding for a term of 3 years. The members in a committee can vary from 5 (ad hoc committee) to 15 . In some Gaushalas honorary members were also there but they only contribute when funds are required in emergency. The executive committee has the full responsibility of Gaushala which includes supervising, managing, maintaining records and funds and day to day functioning in the Gaushala. This executive committee is selected among the members of the Gaushala committee.

\section{Activities performed by Gaushala}

The Gaushalas have various kinds of activities. Their major activity is upkeep and welfare of stray and injured cattle, unproductive cattle left by villagers and animals saved by police from butchers etc., sale of pure milk, sale of various medicinal

Table 1 Average number of animals kept in the Gaushalas

\begin{tabular}{lllc}
\hline S. No. & District & Name of the Gaushala & Number of cattle (2016) \\
\hline 1 & Ambala & Shri Krishan Gaushala, Naraingarh & 1588 \\
2 & Bhiwani & Shri Gaushala, Bhiwani & 2248 \\
3 & Hisar & Shri Haryana Gaushala, Hansi & 3144 \\
4 & Jind & Rashtriya Gaushala, Dharoli, & 3098 \\
5 & Kaithal & Shri Kurukshetra Gaushala, Kaithal & 1982 \\
6 & Karnal & Shri Krishan Gaushala, Karnal & 982 \\
7 & Kurukshetra & Shri Krishan Gaushala, Laadwa & 584 \\
8 & Panipat & Shri Gaushala Samiti, Panipat & 2884 \\
9 & Rohtak & Akhil Bhartiya Gaushala, Peharawar & 5775 \\
10 & Yamunanagar & Shri Gaushala, Jagadhari & 752 \\
\hline
\end{tabular}


Figure 4 Net income across Gaushalas (00000 ₹ / year)

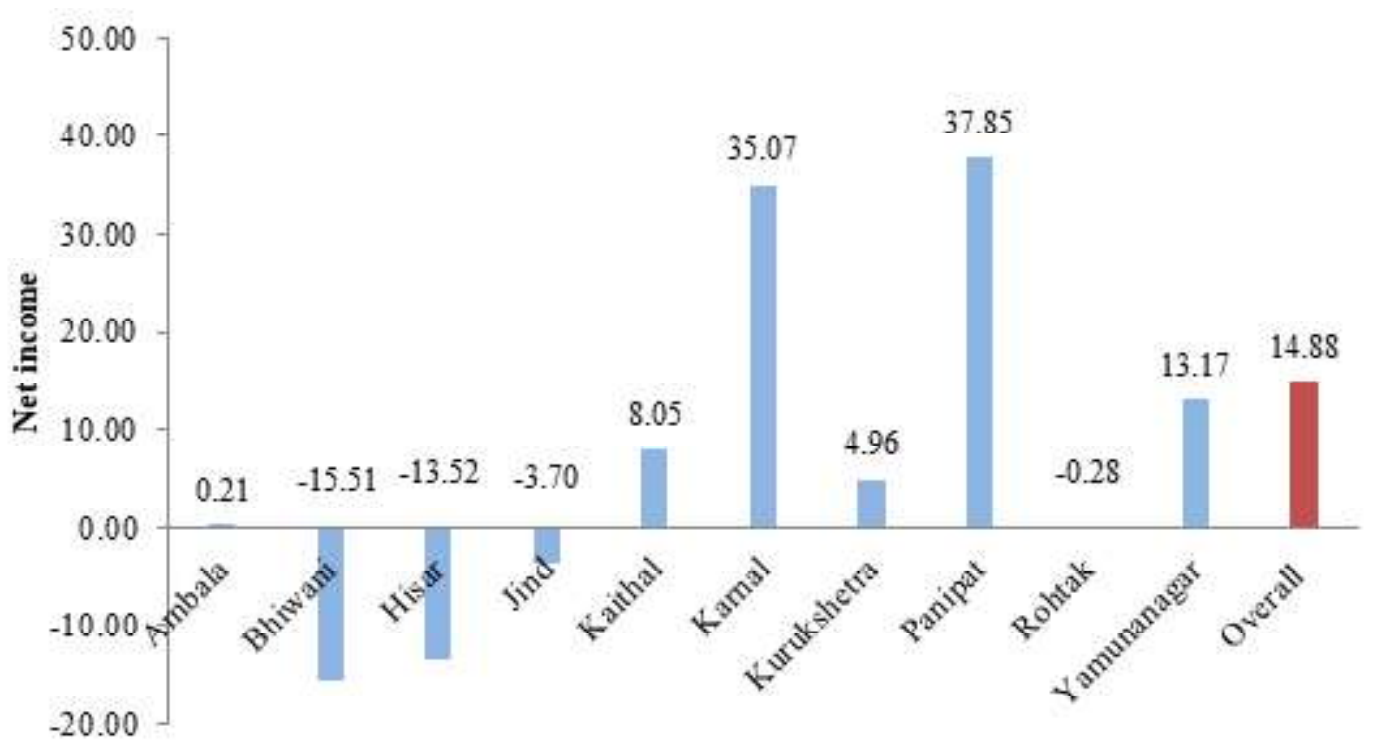

Districts/Gaushalas

Table 2 Standard animal units for northern region of India

\begin{tabular}{llc}
\hline Animals & Crossbred cattle & Local cattle \\
\hline Adult male ( $\geq 3$ years) & 1.27 & 1.08 \\
Adult female ( $\geq 3$ years) & 1.27 & 1.00 \\
Young stock male $(<1$ year) & 0.41 & 0.39 \\
Young stock female ( $<1$ year) & 0.41 & 0.39 \\
Young stock male ( $>$ 1 year) & 0.61 & 0.54 \\
Young stock female ( $>1$ year) & 0.52 & 0.46 \\
Heifer $(1-3$ years) & 078 & 073 \\
\hline
\end{tabular}

Table 3: Total Gaushala area and farm area across Gaushalas (hectare)

\begin{tabular}{lllc}
\hline Districts/Gaushala & Gaushalaarea & Earmarea & Totalarea \\
Ambala & 3.6 & 0 & 3.6 \\
Bhiwani & 3.2 & 0 & 3.2 \\
Hisar & 5.2 & 5.6 & 10.8 \\
Jind & 4.2 & 3.2 & 7.4 \\
Kaithal & 1.8 & 5.2 & 7.0 \\
Karnal & 1.6 & 0 & 1.6 \\
Kurukshetra & 1.1 & 0 & 1.1 \\
Panipat & 6.6 & 10 & 16.6 \\
Rohtak & 4.1 & 8.1 & 12.1 \\
Yamunanagar & 1.2 & 5.6 & 6.8 \\
\hline
\end{tabular}

and products made from cow dung, cow urine and cow milk, sale of heifers, cow and service bulls, sale of grains and organization of trainings and several cultural activities. These cultural activities also help in generation of funds to the Gaushala.

Income and expenses of Gaushala
The data on average annual income and expenditure of Gaushalas in the study area is compiled in figures 5 and 6 respectively which shows the percentage contribution of sources of income and expenditure.

Donations have the largest share (75\%) in total income of the Gaushalas. The various sources of donations found were Gau Gras, donation box, temple donation, donation in festivals and 
Figure 5 Returns over variable cost across Gaushalas $\left(00000^{1} /\right.$ year $)$

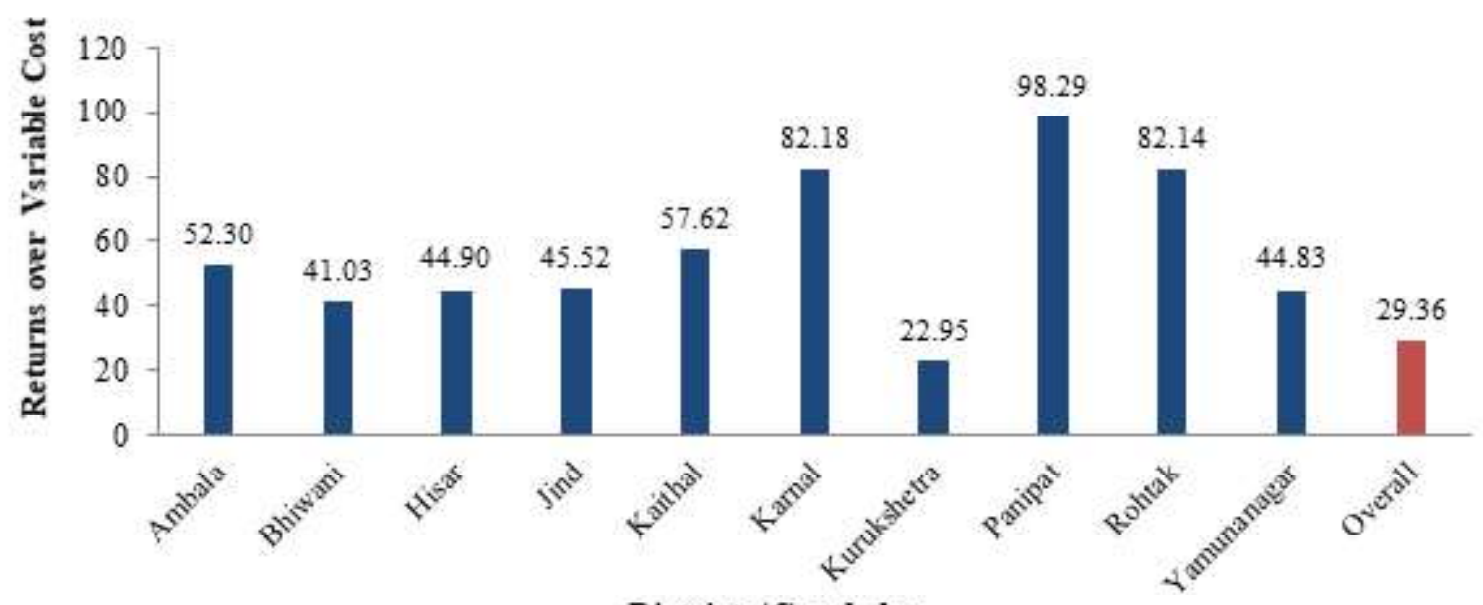

Districts/Gaushalas

Table 4 Average production and sale of milk in the Gaushalas

(litre/ day)

\begin{tabular}{llllc}
\hline S. No. & $\begin{array}{l}\text { District/ } \\
\text { Gaushala }\end{array}$ & $\begin{array}{l}\text { Average quantity of } \\
\text { milk produced }\end{array}$ & $\begin{array}{l}\text { Average quantity of } \\
\text { milk sold }\end{array}$ & $\begin{array}{c}\text { Price received } \\
\text { (Rs./ litre) }\end{array}$ \\
\hline 1 & Ambala & 220 & 195 & 40 \\
2 & Bhiwani & 100 & 62 & 50 \\
3 & Hisar & 20 & - & - \\
4 & Jind & 20 & - & - \\
5 & Kaithal & 500 & 483 & 42 \\
6 & Karnal & 525 & 467 & 44 \\
7 & Kurukshetra & 4 & - & - \\
8 & Panipat & 500 & 450 & 47 \\
9 & Rohtak & 250 & 200 & 40 \\
10 & Yamunanagar & 260 & 240 & 35 \\
& Overall & 402 & 364 & 42 \\
\hline
\end{tabular}

cultural activities, monthly member's contribution, donation for fodder and shed construction etc. Grants given by government contribute $7 \%$ to gross income. Apart from these fund sources, Gaushalas also sell some products such as milk, compost, cow dung and urine, ark, scrap sales, sale of cows, heifers, sale of grains etc. The miscellaneous income includes discount received, interest on deposits, cow awards etc. The income received from sales contributes $12 \%$ to gross income and miscellaneous income contributes almost $5 \%$ to gross income (table 5).

In case of expenses (table 6), the major expenditure was on feed and fodder in the Gaushalas (50\%) After feeding expenses, miscellaneous expenses were found as major operational expenses (11\%) followed by labour expenses (10\%). Miscellaneous expenses include expenses on repair and maintenance, office and stationary items, petrol and diesel, travelling, utility and other bills, kitchen, agricultural, cultural expenses and expenses on sundry items. The Fixed expenses contribute $26 \%$ of total expenses which includes salaries given to employees $(2.56 \%)$ and depreciation of inventory of Gaushalas (23.68\%). The expenses do not include land as these are donated to Gaushalas. The inventory of the Gaushalas includes cattle sheds, stores for fodder, chaff cutters, office buildings, vehicles, machines and equipments with the Gaushalas.

\section{Net income across Gaushalas}

The net income of the Gaushalas is shown in figure 4 . The data is average of net income for 3 years consecutively $(2014,2015$ and 2016). The figure reveals that net income was found negative for Gaushalas in Bhiwani, Hisar, Jind and Rohtak. One reason for their negative net income can be large fixed expenses and large number of animals in these Gaushalas as compared to another Gaushalas. Over all the net income was found positive ( $₹ 14$ lakhs per annum) for whole sample. Panipat Gaushala had the highest net income (₹ 37.85 lakh per annum), while Bhiwani Gaushala had the lowest net income (₹-15.51 lakh per annum). The reason for this can be less diversification and large number of animals (1968) and because of large number of animals, the gross income per animal they receive was lower as compared to another Gaushalas. The same applies to other Gaushalas with negative net income. But, Panipat Gaushala had the highest net income in spite of 


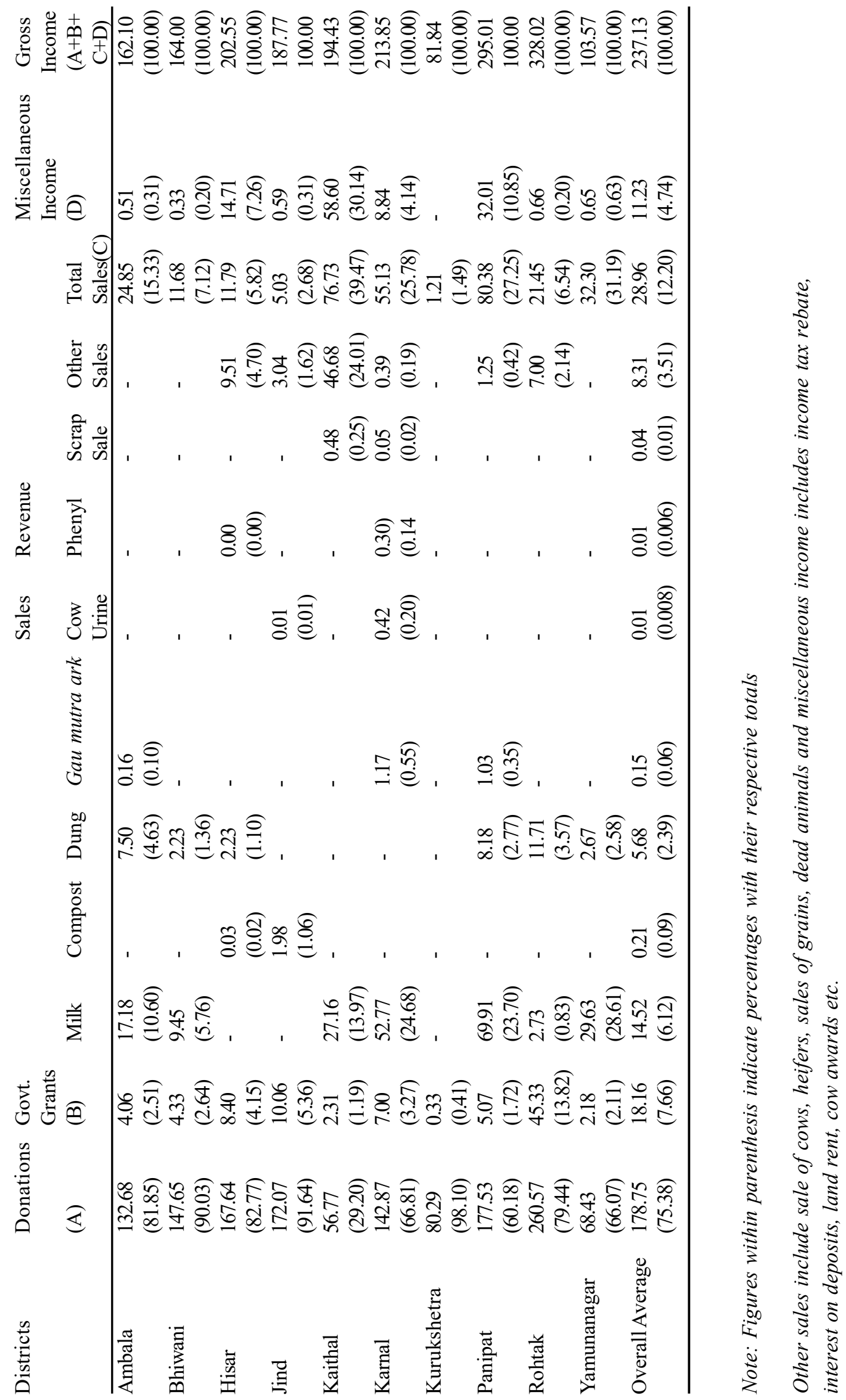


large number of animals. This was because it had much higher gross income than other Gaushalas both in terms of donations

and sales revenue. Same findings were reported by Dixit (1999) in Mandya district of Karnataka and by Mankar (2003) in Wardha district of Maharashtra, where net income for indigenous cattle came out to be negative. Positive net income was only found in case of crossbred cows.

\section{Returns over variable cost across Gaushalas}

Net income was found negative for some Gaushalas because of addition of fixed expenses in total expenses of Gaushalas, but the returns over variable cost was found positive for all the Gaushalas (Figure 5). The data is average of net income for 3 years consecutively $(2014,2015$ and 2016).The average return over variable cost for whole sample was ₹ 29.36 lakh per annum. It indicates that the selected Gaushalas were able to meet their operational expenses and these can be run successfully in the short run. But for long term sustainability net income has to be positive. Panipat Gaushala had the highest return over variable cost (₹98.29 lakh per annum) while Gaushala had the lowest return over variable cost (₹ 22.94 lakh per annum). The Gross income of Panipat Gaushala was $60 \%$ more than the Kurukshetra Gaushala. This was because of large donation received by Panipat Gaushala (₹ 1.77 crore) as compared to Kurukshetra Gaushala (₹ 81 lakhs) and also its sale contributes $27 \%$ to gross income, while sales had only $2 \%$ share in gross income in case of Kurukshetra Gaushala.

\section{Profitability/ ratio analysis}

Ratio Analysis is an important tool to know about the profitability of the Gaushalas and to understand other financial implications (Table 7). It consists of three types of ratios viz. fixed, operating and gross ratio.

The Gross ratio was found to be 0.97 (whole sample). This means that on an average these Gaushalas were spending almost all of their income (97\%) in covering their total expenses. The Gaushalas in Bhiwani, Hisar and Jind were completely at loss which can be seen with a gross ratio more than one. On the other hand the operating ratio for all the Gaushalas was less than one. It shows that Gaushalas were able to cover their working expenses, but on long term basis they were not able to cover their total expenses which can be reapproved by the result that some Gaushalas had negative net income, but return over variable cost was positive for all.

\section{Conclusions}

Though the results prove the profitability as Gaushalas were getting sufficient returns to cover their operating expenses, but, 
Table 7 Ratio Analysis

\begin{tabular}{lllll}
\hline S. No. & Districts/ Gaushalas & Fixed Ratio & Operating Ratio & Gross Ratio \\
\hline 1 & Ambala & 0.32 & 0.68 & 1.00 \\
2 & Bhiwani & 0.34 & 0.75 & 1.09 \\
3 & Hisar & 0.29 & 0.78 & 1.07 \\
4 & Jind & 0.26 & 0.76 & 1.02 \\
5 & Kaithal & 0.25 & 0.70 & 0.96 \\
6 & Karnal & 0.22 & 0.62 & 0.84 \\
7 & Kurukshetra & 0.22 & 0.72 & 0.94 \\
8 & Panipat & 0.20 & 0.67 & 0.87 \\
9 & Rohtak & 0.25 & 0.75 & 1.00 \\
10 & Yamunanagar & 0.31 & 0.57 & 0.87 \\
& Overall & 0.27 & 0.70 & 0.97 \\
\hline
\end{tabular}

to be successful on long term basis it is important to meet up the total expenses which is yet to be achieved by all the Gaushalas. The same conclusion can be drawn on the basis of profitability ratios. Though a considerable part of their income comes from donation, but it is not a permanent source of income. In order to be viable in long run these Gaushalas need to make them self sufficient. Gaushalas should explore the options available to them. Diversification and commercialization seems to be better option. Cow urine, dead animals' skin, hoofs etc can be used to prepare various products or can be sold. These are some ways to diversify the income of the Gaushalas which will make them self- sufficient.

At the same time, even if the Gaushalas become successful in implementing all above solutions, yet lack of space remains a great hindrance in way of achieving self sufficiency because of the ever increasing stray cattle population and stagnant number of Gaushalas on limited lands. This is where government efforts become essential. The Gaushalas infrastructure should be built efficiently so as to accommodate adequate number of animals in Gaushalas. Hence proper government attention towards these institutions is extremely important as they are the centre for our indigenous genetic resource base.

\section{Acknowledgements}

This paper is part of the study conducted for partial fulfillment of the master degree programme in Agricultural Economics of the author from ICAR-National Dairy Research Institute, Karnal, Haryana. The thesis was submitted in 2017 and the title was "Economic Study of Gaushalas in Haryana".

\section{References}

Dixit PK (1999) Bovine economy in Mandya district of Karnataka state - sustainability oriented analysis. Ph.D. Thesis. ICAR National Dairy Research Institute (Deemed University), Karnal- 132001, Haryana, India

Government of Haryana (2016) Statistical Abstract of Haryana, 2014-15 \& 2015-16. Department of Economic and Statistical Analysis, Haryana

Government of India (2014) $19^{\text {th }}$ Livestock Census, 2012. All India Report. Ministry of Agriculture, Department of Animal Husbandry, Dairying and Fisheries. Krishi Bhawan, Delhi, 2014

Mankar GM (2003) Economics of milk production and disposal pattern in Wardha district of Maharashtra. M.Sc. Dissertation. ICAR National Dairy Research Institute (Deemed University), Karnal132001, Haryana, India

Sirohi S, Bardhan D, Chand P (2015) Cost and returns in milk production: Developing standardized methodology and estimates for various production systems. Project Report submitted to department of Animal Husbandry Dairying and Fisheries, Ministry of Agriculture, Govt. of India, New Delhi 